\title{
Technological model of water contact iron removal
}

\author{
Serhii MARTYNOV ${ }^{1)}$ ABCDEF, Victor FYLYPCHUK ${ }^{2) ~ A B C D, ~}$ \\ Vitalii ZOSHCHUK $^{3) \text { BCDF, Serhii KUNYTSKYI }}{ }^{4) \text { BCDEF }}$, Andrii SAFONYK ${ }^{\text {5) ACDE }}$, \\ Oleg PINCHUK ${ }^{\text {() BDEF } \square}$
}

${ }^{1)}$ National University of Water and Environmental Engineering, Department of Water Supply, Water Disposal and Drilling Engineering, Ukraine; e-mail: s.y.martynov@nuwm.edu.ua

2) National University of Water and Environmental Engineering, Department of Labour Security, Health and Safety, Ukraine; e-mail: v.l.fylypchuk@nuwm.edu.ua

3) National University of Water and Environmental Engineering, Department of Labour Security, Health and Safety, Ukraine; e-mail: v.o.zoshchuk@nuwm.edu.ua

4) orcid.org/0000-0003-0318-6149; National University of Water and Environmental Engineering, Department of Science and Research, Ukraine; e-mail: s.o.kunytskiy@nuwm.edu.ua

${ }^{5)}$ orcid.org/0000-0002-5020-9051; National University of Water and Environmental Engineering, Department of Automation, Electrical and Computer-Integrated Technologies, Ukraine; e-mail: safonik@ukr.net

6) orcid.org/0000-0001-6566-0008; National University of Water and Environmental Engineering, Department of Hydroinformatics, 11 Soborna St., Rivne, 33028, Ukraine; e-mail: o.1.pinchuk@nuwm.edu.ua

For citation: Martynov S., Fylypchuk V., Zoshchuk V., Kunytskyi S., Safonyk A., Pinchuk O. 2018. Technological model of water contact iron removal. Journal of Water and Land Development. No. 39 p. 93-99. DOI: 10.2478/jwld-2018-0063.

\begin{abstract}
Different types of filters are used to remove iron from underground water, one of them is foam polystyrene. Depending on the chemical water composition, tasks for water supply and other working conditions of iron-removing filters, it is necessary to define an exact grain size, specific granulometric composition, the thickness of the layer and the adequate rate of filtration. This kind of problems is multifactorial and its solution is based on the mathematical modelling.

As a rule, two parallel processes considered during iron removal of underground water in filters: efficiency of water treatment and growth of head losses. Therefore, the model of water iron removal based on two main blocks, clarifying block takes into account the material balance and kinetics of the process; hydrodynamic block describes the dynamics of head loss in the granular loading. The kinetics of the detention of iron compounds in granular loading consists of two mutually opposite processes. With an increase of the amount of adsorption-catalytic precipitate, the rate of sorption of iron compounds and oxidation of ferric iron increases and the efficiency of iron-removing increases. On the other hand, with decreasing porosity of loading the true velocity of the fluid increases, that reduces the intensity of adhesion of iron compounds.

Developed mathematical model allows for determining optimal values of structural and technological parameters of iron-removing filters taking into consideration the specific filtering conditions.
\end{abstract}

Key words: foam polystyrene filter, iron removal, mathematical model, underground water, water treatment technology 


\section{INTRODUCTION}

The state of water resources and water supply of the population of any country remains one of the main actual threats to national security in the environmental sphere. In modern society, rational use of water resources, in the conditions of water shortage, deterioration of its quality is a complex scientific and technical problem [ATTOUI et al. 2016; LIEFFERINK et al. 2017; ORLOV et al. 2016a].

An important place in the field of water supply takes the process of water preparation. In recent years, the purification of natural water, improvement of water preparation technologies and development of new effective resource-saving methods becomes more and more actual [HANSLIK et al. 2016; SHIRAZI et al. 2015]. European Union devoted to surface and ground water protection. The directive attributes a great role to the protection of aquatic and water related ecosystems [MIODUSZEWSKI 2009].

Water supply of most small and medium-sized settlements carries out by underground sources [ORLOV et al. 2016a, c; STANKJAVICHUS 1978].

This is almost the entire population in Ukraine of northern, western, northeastern and other regions. In most cases, underground water contains high amount of iron (usually to $3 \mathrm{mg} \cdot \mathrm{dm}^{-3}$ ), hydrogen sulphide, free carbon dioxide [ORLOV et al. 2016b; SMOROŃ 2016].

Excessive amounts of iron in the water not only causes formation of unpleasant smells, turbidity, colour of water, overgrown of water pipes but also adversely affects human health [GANG 2017; SHIRAZI et al. 2015]. Therefore, before using water for drinking purposes is necessary to remove this component.

In recent years, the purification of natural water, improvement of water preparation technologies and development of new effective resource-saving methods becomes more and more actual [VOLTZ et al. 2014].

Iron removal method chosen depending on the chemical water composition, the degree of iron-removing, water treatment station productivity, etc. [CONNER 1989; KHATRIA et al. 2017; MARSIDI, ABDULLAH 2018], based on the technological tests. Most often nonchemical method is used for iron-removing of water because it is easier and cheaper [JECHLINGER, KASPER 1985].

The effectiveness of iron removal of water in granular filters depends on many factors that can be grouped into the following major groups: physicochemical indicators of quality of underground water, characteristics of the filters downloading, method of water preparation before its filtration, technological parameters of filters work [EPOYAN et al. 2018; POLYAKOV 2011].

For iron removal of underground water are used various types of filtering downloads [BARLOKOVA, ILAVSKY 2010; MADHUKAR et al. 2013]. The construction of the filtering equipment and auxiliary equipment usually depends on the type of downloads. The use of "heavy" downloads (sand, gravel, zeolite, etc.) require additional equipment for organization of washing. However, coarsegrained downloading, such as granite gravel, requires very high airflow and washing water. Therefore, the operation of such filters is complicated. Using zeolite downloads allows to receive filtrate of high quality and carry out washing quite effective. However, zeolite is quickly erased and washed out during washing that requires its periodic additional downloads [ORLOV et al. 2016b].

Polystyrene foam downloading performs water iron removal enough effectively. In this case the effective downloading washing performed by the easiest way [FYLYPCHUK et al. 2017; SAFONYK et al. 2018]. Expanded polystyrene proposed to use as download of fast filters for the first time at the Department of Water Supply and Drilling UIIWM (now National University of Water and Environmental Engineering, Ukraine). Many national and foreign scientists are engaged in research of foam polystyrene filters [LAVANYA et al. 2014; MADHUKAR et al. 2013].

During the water iron-removing for medium and large customers we proposed and introduced the foam polystyrene free-flow filters with increasing particle size granules, with ascending filtration in a number of water treatment stations in Ukraine. Using as downloading polystyrene foam granules industrial production allows to reduce the costs for purchasing downloading in 4.5 times. For iron-removing of water for small consumers, mostly rural water pipelines, in the presence the steel water tower, it is expedient to contain the iron-removing equipment in it, the tower station of water iron removal [ORLOV et al. 2012].

Filters must be assigning by specific granulometric composition, layer thickness and accordingly the rate of filtration, depending on the chemical water composition, appointments of water supply and other conditions for iron removal [POLYAKOV 2011]. Such task is multifactorial and its solution should be performing using mathematical modelling.

Among the directions of research on intensifying the work of filtering structures, it is necessary to highlight the development of improved mathematical models and methods of calculation, and, first of all, the use of computer technologies [ATTOUI et al. 2016; IVANCHUK et al. 2017; MARTYNIUK et al. 2018; MARTYNOV et al. 2017; ORLOV et al. 2016c: VLASYUK et al. 2017 ].

Therefore, the main task of the work was to develop a mathematical model of technological contact iron-removing of water and its approbation involving experimental data.

\section{MATERIALS AND METHODS}

Due to complex assessment of processes taking place in aquifers, mathematical modelling is the best tool supporting evaluation off pollution in the ground water environment. It is also an effective method of forecasting the risk associated with the harmful impact of objects polluting grounds and grounds waters [ŚLESICKI 2009].

During researches, we used physical modelling process of water iron-removing in laboratory conditions on foam polystyrene filter. Water with high concentrations of iron was prepared using iron sulphate, which was entering in tap water that was supplying into the station. Determined the head loss in the granular downloading used the shield of piezometer, the concentration of iron in the input water, alkalinity, $\mathrm{pH}$, temperature and several other para- 
meters. For the forecasting of foam polystyrene filters work was used mathematical modelling, which solved using numerical method in the application program.

During the groundwater iron-removing in filters usually considered two parallel processes: the water treatment efficiency and increased of head loss, as with clarifying of surface water [POLYAKOV 2009]. The first process is the main and second is the accompanying. Therefore, the model of water iron removal should base on two main blocks: clarifying (deformation) block takes into account the material balance and the kinetics of the process; hydrodynamic (filtration) block describes the dynamics of head loss in the granular downloading [MARTYNOV et al. 2017].

The equation of material balance can represent by the following equation:

$$
V \frac{\partial C}{\partial x}+\frac{\partial \rho}{\partial t}=0
$$

Where: $V=$ the filtration rate, $\mathrm{m} \cdot \mathrm{h}^{-1} ; C=$ the concentration of iron, $\mathrm{mg} \cdot \mathrm{dm}^{-3} ; x=$ the coordinate to the height of downloads, $\mathrm{m} ; \rho=$ the sediment concentration in the solid phase, $\mathrm{mg} \cdot \mathrm{dm}^{-3} ; t=$ the filtration duration, $\mathrm{h}$.

It is known, that the sediment of the iron hydroxide is simultaneously not only a catalyst, but also an adsorbent concerning the iron compounds, i.e. is an adsorption catalyst. Therefore, the kinetics of detention iron compounds in the granular downloading consists of two mutually opposing processes. With increasing the number of adsorptioncatalytic sediment the rate of sorption of iron compounds and oxidation of ferrous iron are increasing. The iron removal efficiency is increasing. On the other side, with decreasing of downloads porosity the true speed of liquid increases that reduces the intensity of adhesion of iron compounds.

If at the beginning of filtration the adsorption-catalytic forces dominated the hydrodynamic forces of the flow then the iron removal efficiency will be improved to the time when these forces do not become equal (Fig. 1, point $\tau_{0}$ ).

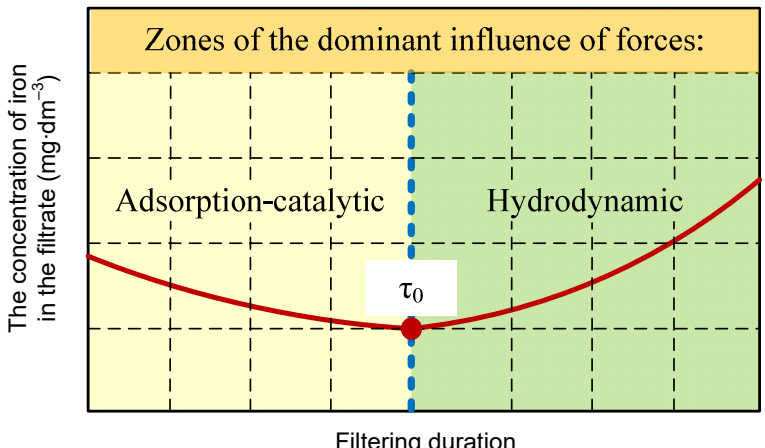

Fig. 1. Changing the concentration of total iron in the liquid phase of granular downloads during filtration; source: own elaboration

Then there is decreasing of the particles detention in the first layers of downloads with the transfer of the front pollution into the following layers in the course of movement of liquid. There is a gradual maximum saturation of downloads off pollution. Formed porous channels with high-speed liquid in them, where occurring colmatation of grains downloads. With sufficient reserve of pressure, the duration of such period may be 3.5-10 days.

According to some researchers the sediment that accumulates in the pore space of downloads at the contact iron-removing has the gel-like form and practically does not occur the avulsion of particles even at filtration rates over $100 \mathrm{~m} \cdot \mathrm{h}^{-1}$ [STANKJAVICHUS 1978]. Therefore, it is appropriate to consider the unseparated kinetic of process.

Given the above, the equation of kinetics of iron-removing of water looks as following:

$$
\frac{\partial \rho}{\partial t}=\frac{\varphi \prime\left(\rho_{\max }-\rho\right) \beta \alpha_{f} C}{V d}
$$

Where: $\varphi^{\prime}=$ the coefficient that determines the autocatalytical impact of sediment to the process of iron-removing of water and can be defined by the formula $4 ; \rho_{\max }=$ the limit of sediment concentration per unit volume of the filter; $\beta=$ the kinetic coefficient that determines the rate adhesion of suspended solids; $\alpha_{f}=$ the coefficient of grains form; $d=$ the diameter of grains downloads.

In case of earnings, the various forms of iron to filter (ferrous and oxidative) coefficient $\beta$ can determine by the formula:

$$
\beta=K^{\prime} \varepsilon+\beta^{\prime}(1-\varepsilon)
$$

Where: $K^{\prime}, \beta^{\prime}=$ the sorption constants of ferrous and oxidative iron in the solid phase; $\varepsilon=C_{2} / C=$ the ratio of the concentration of ferrous iron $C_{2}$ to the concentration of total iron $C$.

Due to nonlinearity the process of the contact iron-removing of water, the coefficient $\varphi^{\prime}$ advisable to represent as follows:

$$
\varphi^{\prime}=\left(\frac{\rho}{\rho_{\max }}\right)^{\varphi}
$$

The impact of coefficient $\varphi^{\prime}$ to the concentration of total iron in the filtrate is shown in Fig. 2.

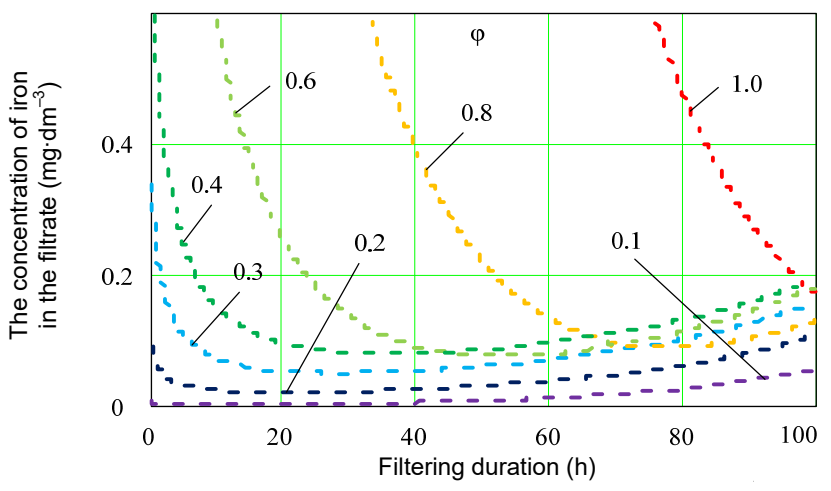

Fig. 2. Changing the iron concentration in the filtrate at different values of the coefficient $\varphi$; source: own elaboration

Therefore, with the increasing of the coefficient $\varphi^{\prime}$, the effectiveness iron-removing of water increasing i.e. increased the adsorption-catalytic properties of sediment. Based on computer modelling involving experimental data in further calculations accept the coefficient values $\varphi^{\prime}=0.3$. 
Table 1. Values of parameters and coefficients of a mathematical model

\begin{tabular}{|c|c|c|c|c|c|c|c|c|c|c|c|c|c|c|c|c|c|c|}
\hline \multirow{2}{*}{$\begin{array}{c}\text { Parame- } \\
\text { ter, } \\
\text { coeffi- } \\
\text { cient }\end{array}$} & \multicolumn{18}{|c|}{ Value at $C_{0}\left(\mathrm{mg} \cdot \mathrm{dm}^{-3}\right)$} \\
\hline & 1.0 & 1.5 & 2.0 & 1.0 & 1.5 & 2.0 & 1.0 & 1.5 & 2.0 & 1.0 & 1.5 & 2.0 & 1.0 & 1.5 & 2.0 & 1.0 & 1.5 & 2.0 \\
\hline$V\left(\mathbf{m} \cdot h^{-1}\right)$ & \multicolumn{3}{|c|}{3.0} & \multicolumn{3}{|c|}{4.0} & \multicolumn{3}{|c|}{5.0} & \multicolumn{3}{|c|}{6.0} & \multicolumn{3}{|c|}{7.0} & \multicolumn{3}{|c|}{8.0} \\
\hline$\beta, 10^{-4}$ & 3.2 & 2.5 & 2.5 & 3.6 & 2.6 & 2.5 & 4.5 & 2.6 & 2.7 & 4.5 & 3.6 & 3.6 & 4.5 & 4.6 & 3.6 & 4.5 & 4.5 & 3.9 \\
\hline$\rho_{0}$ & 1.5 & 10.0 & 10.0 & 3.1 & 3.8 & 10.0 & 5.4 & 1.2 & 10.0 & 4.0 & 5.9 & 10.0 & 4.0 & 1.6 & 10.0 & 10.0 & 10.0 & 10.0 \\
\hline$\rho_{\max }$ & 1500 & 1300 & 1300 & 2200 & 1400 & 1300 & 2200 & 1510 & 1300 & 2200 & 1300 & 1300 & 2200 & 1400 & 1530 & 2200 & 1340 & 1420 \\
\hline$\gamma$ & 20000 & 15000 & 15000 & 15000 & 15000 & 15000 & 20000 & 15000 & 15000 & 20000 & 15000 & 15000 & 20000 & 15000 & 20000 & 20000 & 15000 & 20000 \\
\hline 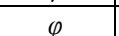 & 0.4 & 0.4 & 0.4 & 0.4 & 0.28 & 0.28 & 0.39 & 0.2 & 0.2 & 0.33 & 0.2 & 0.2 & 0.31 & 0.2 & 0.2 & 0.27 & 0.2 & 0.2 \\
\hline$\Delta^{2}, 10^{-4}$ & 11 & 3.7 & 17 & 5.3 & 13 & 7.2 & 5.5 & 11 & 7.2 & 9.1 & 14 & 15 & 22 & 28 & 77 & 24 & 29 & 100 \\
\hline
\end{tabular}

Explanations: $\beta=$ the kinetic coefficient that determines the rate adhesion of suspended solids, $\rho_{0}=$ the initial sediment concentration, $\rho_{\text {max }}=$ the limit of sediment concentration per unit volume of the filter, $\gamma=$ the density of solid sediment, $\varphi=$ coefficient.

Source: own elaboration.

The equation of the active downloads porosity changes:

$$
m_{E}=m_{0}-\frac{\rho}{\gamma}
$$

Where: $m_{0}=$ the primary porosity of downloads; $\gamma=$ the density of solid sediment (mass concentration in unit of sediment volume).

The geometric structure of porous medium changes during water filtering through granular downloads in a result of accumulation sediment in the intergranular space. As a result, the hydraulic resistance of downloads and head losses in it increased. Head losses in the granular layer depend on many factors: the height of downloads layer, structural indicators of downloads (minimum, maximum, equivalent diameters, the coefficient of grains form, porosity), filtering rate, temperature (viscosity) of water, an amount, the character and distribution for the height of downloads pollution and so on. If the water filtration is occurring in the laminar mode for which Darcy equation is true, so hydraulic incline is convenient to determine by the Koseny-Karman equation:

$$
I=\frac{V v}{0.55}\left(\frac{\alpha_{f}}{d}\right)^{2} \frac{\left(1-m_{E}\right)^{2}}{m_{E}{ }^{3}}
$$

Where: $v=$ the coefficient of viscosity of water.

The total head loss in the foam polystyrene downloads:

$$
H_{d}=\int_{x=0}^{x=L} I d x
$$

Where: $L=$ the total height of downloads.

The initial and boundary conditions:

at $x=0 \rightarrow C=C_{0}$; for $t=0 \rightarrow \rho=\rho_{0}(x)$;

for $x=L \rightarrow C \leq C_{\mathrm{ALL}}$;

at $t=t_{f} \rightarrow H_{d} \leq H_{\mathrm{ALL}}$;

for $t \rightarrow \infty \rightarrow \frac{\partial C}{\partial x}=0, C=C_{0}, \rho=\rho_{\max }$

Where $C_{\mathrm{ALL}}=$ the maximum allowable concentration of total iron in the filtrate; $t_{f}=$ the standard duration of filtering; $H_{\mathrm{ALL}}=$ the maximum allowable head losses in the downloads.

The mathematical model solved by numerical method in Annex MathCAD with the following parameters: downloads height $H_{d}=1.0 \mathrm{~m}$, step by downloads height $\Delta x=$ $0.01 \mathrm{~m}$, the time step $\Delta t=0.1 \mathrm{~h}$, the water temperature
$I=12^{\circ} \mathrm{C}$, filtering duration $t_{0}=8 \mathrm{~h}$, equivalent diameter $d=0.0028 \mathrm{~m}$, coefficient of grains form $\alpha_{f}=1.05$, filtering rate $V=3-8 \mathrm{~m} \cdot \mathrm{h}^{-1}$, input iron concentration $C_{0}=1-2$ $\mathrm{mg} \cdot \mathrm{dm}^{-3}$.

The coefficients of a mathematical model $\left(\beta, \rho_{0}, \rho_{\max }, \gamma, \varphi\right)$ determinate in MathCAD based on the results of experimental research using the function Minimize:

$$
\left(\begin{array}{c}
\beta \\
\rho_{0} \\
\rho_{\max } \\
\gamma \\
\varphi
\end{array}\right):=\text { Minimize } f\left(\beta, \rho_{0}, \rho_{\max }, \gamma, \varphi\right)
$$

Criteria of the optimal coefficients values served the minimum value of the sum of difference of squares calculation and experimental values. Results of calculations are shown in Table 1.

\section{RESULTS AND DISCUSSION}

As a result of identification of mathematical model coefficients established their average values: $\beta=3.6 \cdot 10^{-4}$, $\rho_{0}=7 \mathrm{mg} \cdot \mathrm{dm}^{-3}, \rho_{\max }=1600 \mathrm{mg} \cdot \mathrm{dm}^{-3}, \gamma=16000 \mathrm{~kg} \cdot \mathrm{m}^{-3}$, $\varphi=0.3$. Figure 3 presents results of experimental research (lines) and calculated data (symbols).

Thus, the calculated values quite good agreed with the experimental results.

For the increase of efficiency of water iron-removing especially in the first hours of filtering it is advisable to perform incomplete washing when the part of sediment are staying in the porous media of downloads after washing. However to control this indicator value is quite difficult and probably impossible. Accordingly, the duration of washing or concentration of the suspended solids (iron compounds) in the wash water may be controlled. Thus, it was considered incomplete such washing at which concentration of iron compounds at the end of washing was 20-40 $\mathrm{mg} \cdot \mathrm{dm}^{-3}$. For the laboratory installation the duration of incomplete washing accordingly was around $30 \mathrm{~s}$.

Laboratory researches at incomplete washing of downloads were carried out for the filtering installation with the layer height $1.0 \mathrm{~m}$, in the range of filtration rates $5-7 \mathrm{~m} \cdot \mathrm{h}^{-1}$, the concentration of iron in the input water $1-2 \mathrm{mg} \cdot \mathrm{dm}^{-3}$. The quality of the filtrate was observing better than in the experiments with complete washing. So Figure 4 shows the 
a)

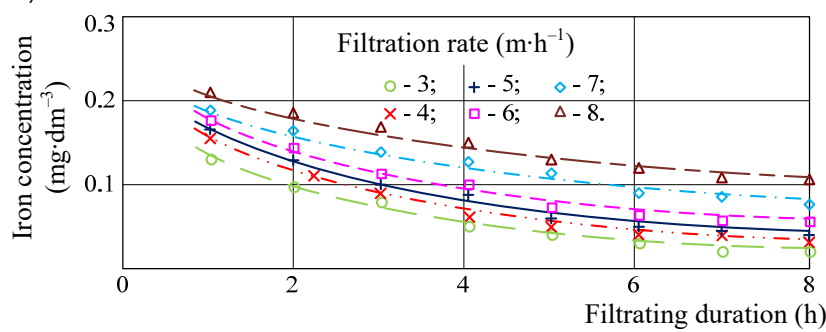

b)

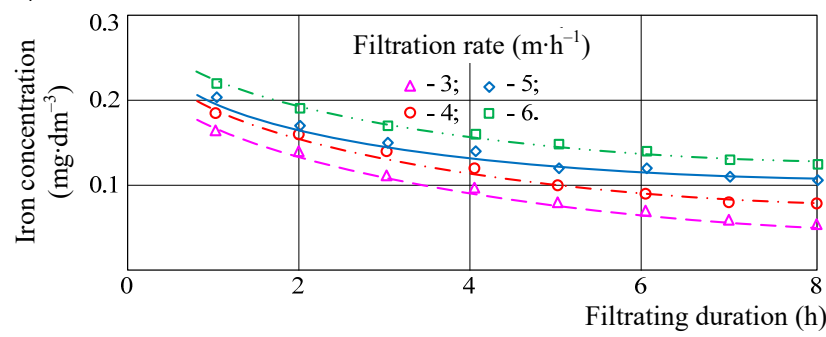

Fig. 3. Changing the iron concentration in the filtrate from the filtering rate and filtering duration for incoming iron concentration of: a) $1.0 \mathrm{mg} \cdot \mathrm{dm}^{-3}$, b) $2.0 \mathrm{mg} \cdot \mathrm{dm}^{-3}$; source: own study

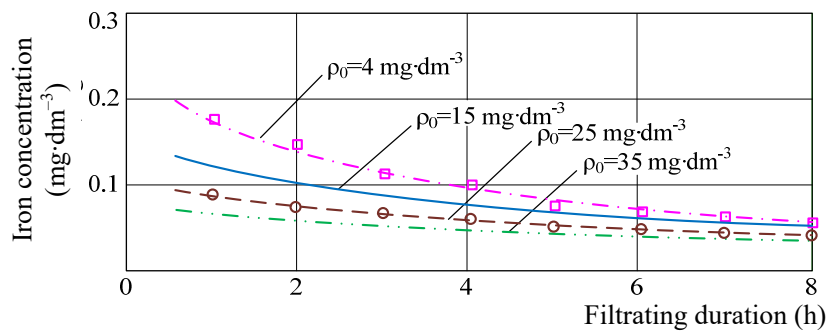

Fig. 4. Changing the iron concentration in filtrate from the initial sediment concentration $\left(\rho_{0}\right)$ at the initial iron concentration of $1.0 \mathrm{mg} \cdot \mathrm{dm}^{-3}$ and the filtering rate $6 \mathrm{~m} \cdot \mathrm{h}^{-1}$; source: own study

results of experimental research of changes the concentration of iron in the filtrate over time depending on the washing methods (complete washing, and incomplete washing) calculated by mathematical model depending on the initial concentration of sediment in the pores of the downloads. Best ratio of experimental data with calculated was for complete washing at $\rho_{0}=4 \mathrm{mg} \cdot \mathrm{dm}^{-3}$, for incomplete washing at $\rho_{0}=25 \mathrm{mg} \cdot \mathrm{dm}^{-3}$.

Initial head losses at incomplete washing were higher. At the same time after 9 filtering cycles $(62 \mathrm{~h})$ by using incomplete washing was observed colmatation (adhesion) the smallest particles of downloads, that is not eliminated even by careful washing of downloads. As a result, the quality of filtrate deteriorated and was $0.3 \mathrm{mg} \cdot \mathrm{dm}^{-3}$ or more. Therefore, despite the best efficiency, iron-removing of water during incomplete washing of downloads and wash water saving, due to reduced washing time, this mode is not recommend to use constantly.

In recent years in Ukraine is observed reducing of water consumption [ORLOV et al. 2016b]. Due to these the operating water intakes are working not at full capacity and they were exploited by groups to provide the support of the well in working condition. In addition, economic factors affects to the operation of water pipelines, which above all, should include changes in the cost of electricity during the day due to the use of multi-zone tariffs for electricity. This variability of work of the water intakes leads to fluctuations of the water quality parameters in it that requires taking into account the stations of water iron removal during projecting and exploitation and primarily filtering stations.

Therefore, in further work is planned to develop a mathematical model that takes into account the detention and transformation of various forms of iron, taking into account the impact on the process of dissolved oxygen and other indicators in the conditions of the irregular work with the involvement of the experimental data from existing municipal water iron removal stations.

\section{CONCLUSIONS}

Therefore, we analysed features of contact iron-removing of underground water and developed a mathematical model of the process, which allows determining the optimal values of structural and technological parameters of the iron removal filters depending on the specific requirements of the designing. Based on experimental researches determined the coefficients of a mathematical model. The calculations by proposed equation are consistent with the results of natural researches. Numerical calculations and experimental research confirmed the effectiveness of water iron-removing at incomplete downloads washing. However, this mode of the filters work requires careful approach to the organization and the control of washing process.

\section{REFERENCES}

Attoui B., Toumi N., Messaoudi S., Benrabah S. 2016. Degradation of water quality: the case of plain west of Annaba (northeast of Algeria). Journal of Water and Land Development. No. 31 p. 3-10. DOI 10.1515/jwld-2016-0031.

BARLOKOVA D., ILAVSKY J. 2010. Removal of iron and manganese from water using filtration by natural materials. Polish Journal of Environmental Studies. Vol. 19. No. 6 p. $1117-1122$.

CONNER D.O. 1989. Removal of iron and manganese. Water Sewage Works. No. 28 pp. 68.

Epoyan S., Karahiaur A., Volkov V., Babenko S. 2018. Research into the influence of vertical drainage elements on the operational efficiency of rapid filters. Eastern-European Journal of Enterprise Technologies. Vol. 1. No 10(91) p. 6269. DOI 10.15587/179-4061.2018.123559.

Fylypchuk V., Induchny S., Pearce P., Fylypchuk L., MarTYNOV S. 2017. Application of expanded polystyrene filter for tertiary treatment of domestic waste effluent in the UK. Journal of Water and Land Development. No. 35 p. 41-47. DOI 10.1515/jwld-2017-0066.

Gang L., Zhang Ya, KnibBe W., Feng C., Wentso L., Medema G., MeER W. 2017. Potential impacts of changing supplywater quality on drinking water distribution: A review. Water Research. Vol. 116 p. 135-148. DOI 10.1016/j.watres.2017. 03.031 .

Hanslik E., Maresova D., JuRanova E., Vlnas R. 2016. Dependence of selected water quality parameters on flow rates at river sites in the Czech Republic. Journal of Sustainable Development of Energy, Water and Environment 
Systems. Vol. 4(2) p 127-140. DOI: 10.13044/j.sdewes. 2016.04.0011.

Ivanchuk N., Martynyuk P., Tsvetkova T., Michuta O. 2017. Mathematical modeling and computer simulation of the filtration processes in earth dams. Eastern European Journal of Enterprise Technologies. No. 2(6) p. 63-69. DOI 10.15587/1729-4061.2017.98712.

JECHLINGER G., KASPER W. 1985. The removal of iron and manganese in groundwater through aeration underground. Water Supply. Vol. 3. p. 19-25.

KhatRia N., Tyagia S., RAWTANi D. 2017. Recent strategies for the removal of iron from water: A review. Journal of Water Process Engineering. Vol. 19 p. 291-304. DOI 10.1016/ j.jwpe.2017.08.015.

LAVANYa R.S., Ulavi S., LOKESH K.S. 2014. Water softening and de-ironing of ground water using sulfonated polystyrene beads. International Journal of Engineering Research and Technology. Vol. 3. Iss. 6 p. 2124-2127.

LiefFerink S.L., VAN EEDEN E.S., WePENER V. 2017. Past, present and future use of municipal water and freshwater resources of the Bekkersdal Community, Westonaria, South Africa. Journal of Sustainable Development of Energy, Water and Environment Systems. Vol. 5(3) p 430-446. DOI 10.13044/j.sdewes. d5.0155.

MadhUKar M., LaVANYA R.S., AmRUtha M.B. 2013. Defluoridation and deironing of ground water using polystyrene beads. Water Science and Technology Water Supply. Vol. 13(6) p. 1507-1512. DOI 10.2166/ws.2013. 116.

MaRSidi N., ABDUllah S. 2018. A review of biological aerated filters for iron and manganese ions removal in water treatment. Journal of Water Process Engineering. Vol. 23 p. 1-12. DOI 10.1016/j.jwpe.2018.01.010.

MartyniUK P.M., KuTIA T.V., OSTAPChUK O.P., PINChUK O.L. 2018. Filtration equation and movement of the wetting interface in case of pressure pipeline breakthrough under the conditions of variable porosity. JP Journal of Heat and Mass Transfer. Vol. 15. Iss. 2 p. 281-293. DOI 10.17654/ HM015020281.

MARTYNOV S., KunitskiY S., ORLOVA A. 2017. A simulation study of surface water purifying through a polystyrene foam filter. Eastern European Journal of Enterprise Technologies. Ecology. Vol. 5. No. 10 (89) p. 19-26.

MiODUSZEWSKI W. 2009. Water for agriculture and natural environment. Journal of Water and Land Development. No. 13b p. 3-16.

ORLOV V., MARTYNOV S., KUNITSKIY S. 2016a. Energy saving in water treatment technologies with polystyrene foam filters. Journal of Water and Land Development. No. 31 p. 119-122. DOI 10.1515/jwld-2016-0042.

ORLOV V., MARTYNOV S., KUNITSKY S. 2016b. Water ironremoving in polystyrene foam filters with sediment layer.
Saarbrücken. LAP LAMBERT Academic Publishing. ISBN 978-3-659-91657-1 pp. 104.

Orlov V., Martynov S., Orlova A. 2012. Ochyshhennya pryrodnoyi vody na pinopolistyrolnyh filtrah [Purification of source water in foam polystyrene filters]. Rivne. NUWEE. ISBN 978-966-327-214-6 pp. 172.

Orlov V., Safonyk A., Martynov S., Kunytskyi S. 2016c. Simulation the process of iron removal the underground water by polystyrene foam filters. International Journal of Pure and Applied Mathematics. Vol. 90. Iss. 2 p. 87-91.

POLYAKOV V.L. 2009. Teoreticheskiy analiz vremeni raboty fil'tra [The theoretical analysis of the filter run time]. Khimiya i Tekhnologiya Vody. Vol. 31. No. 6 p. 605-618.

PolyaKov V.L. 2011. Inzhenernyy raschet fil'tratsii suspenzii cherez dvukhsloynuyu sredu pry lineynoy kinetike massoobmena [The engineering calculation of filtering a suspension through a two-layer medium in linear kinetics of mass exchange]. Khimiya i Tekhnologiya Vody. Vol. 33. No. 4 p. 367-380.

SafonyK A., Martynov S., Kunytskyi S., Pinchuk O. 2018. Mathematical modelling of regeneration the filtering media bed of granular filters. Advances in Modelling and Analysis C. Vol. 73. No. 2 p. 72-78.

ShiraZi S.M., ADHAM M.I., ZARDARi N.H., ISMAIl Z., IMRAN H.M., MANGRIO M.A. 2015. Groundwater quality and hydrogeological characteristics of Malacca state in Malaysia. Journal of Water and Land Development. Vol. 24 p. 11-19. DOI 10.1515/jwld-2015-0002.

SMOROŃ S. 2016. Quality of shallow groundwater and manure effluents in a livestock farm. Journal of Water and Land Development. Vol. 29 p. 59-66. DOI 10.1515/ jwld-2016-0012.

StankJAVICHUS V. 1978. Obezzhelezivanie vody fil'trovaniem (osnovy teorii i raschet ustanovok) [Water iron-removing by filtration (fundamentals of the theory and calculation of installations)]. Vil'njus. Mokslas pp. 120.

ŚLESICKI M. 2009. Application of mathematical modelling methods in the protection of groundwater environment. Journal of Water and Land Development. No. 13b p. 31-39.

Vlasyuk A.P., ZhuKovska N.A., ZhuKOVSKyy V.V., KlosWitKowska A., PAZDriY I., IATSYKovska U. 2017. Mathematical simulation of the stressed-strained state of the foundation of earth dams with an open surface under the influence of heat and mass transfer in the two-dimensional case. In: Intelligent Data Acquisition and Advanced Computing Systems: Technology and Applications. Proceedings of the 2017 IEEE 9th International Conference. IDAACS. Vol. 1 p. 265-269. DOI 10.1109/IDAACS.2017.8095088.

Voltz T.J., GrischeK T., SPITZNER M. KeMNITZ J., IRMSCHER R. 2014. Raising energy efficiency of high-head drinking water pumping schemes in Hilly India - massive potential, complex challenges. Journal of Sustainable Development of Energy, Water and Environment Systems. Vol. 2. Iss. 2 p. 118-126. 


\section{Serhii MARTYNOV, Viktor FYLYPCHUK, Vitalii ZOSHCHUK, Serhii KUNYTSKYI, Andrii SAFONYK, Oleg PINCHUK}

\section{Technologiczny model usuwania żelaza z wody metodą kontaktową}

\section{STRESZCZENIE}

Do odżelaziania wód podziemnych stosowane są różne typy filtrów, jednym z nich są filtry ze spienionego polistyrenu. W zależności od składu chemicznego wody, jej przeznaczenia i warunków pracy filtrów należy określić dokładny rozmiar ziaren, skład granulometryczny, grubość warstwy filtrującej i odpowiednie tempo filtracji. Tego rodzaju problemy są wieloczynnikowe, a ich rozwiązanie opiera się na modelowaniu matematycznym.

Podczas usuwania żelaza $\mathrm{z}$ wody gruntowej $\mathrm{w}$ filtrach $\mathrm{z}$ reguły bierze się pod uwagę dwa równoległe procesy - efektywność uzdatniania wody i wzrost strat w głowicy. Dlatego opracowany model usuwania żelaza z wody oparty jest na dwóch podstawowych blokach: oświetleniowym - uwzględnia się bilans materiałowy i kinetykę procesu; bloku hydrodynamicznym - opisującym dynamikę spadku ciśnienia w ziarnistym wypełnieniu. Kinetyka zatrzymywania związków żelaza w ziarnistym wypełnieniu składa się z dwóch przeciwnych procesów. Wraz ze wzrostem ilości osadu adsorpcyjnokatalitycznego wzrasta też szybkość sorpcji związków żelaza i utleniania żelaza dwuwartościowego, a także zwiększa się skuteczność usuwania żelaza. Z drugiej strony, w warunkach malejącej porowatości wypełnienia, wzrasta rzeczywista prędkość płynu, co zmniejsza intensywność adhezji związków żelaza.

Zbudowany model matematyczny pozwala na określenie optymalnych wartości parametrów strukturalnych i technologicznych dla filtrów usuwających żelazo z uwzględnieniem specyfiki warunków filtracji.

Słowa kluczowe: filtry ze spienionego polistyrenu, model matematyczny, odżelazianie, technologia uzdatniania wody, wody podziemne 